\title{
Mutual Fund Performance and the Impact of Superannuation and Financial Regulation
}

\author{
James M. Cooper \\ Diligentia Venture Partners Ltd \\ Russell Gregory-Allen \\ Massey University \\ *Corresponding author: R. Gregory-Allen@massey.ac.nz
}

\section{A R T I C L E I N F O}

Article history:

Received 22 February 2018

Revised 8 July 2018

Accepted 8 August 2018

Keywords:

Mutual fund performance, Mutual fund regulation, Regulation changes.

JEL Code: G11, G15, G23, G28

\section{A B S T R A C T}

Financial innovation such as a new superannuation scheme can allow for broader participation in retirement savings by individuals, but might also impact existing investments. On the other hand, mutual fund regulation involves a balancing act between protecting investors, and allowing fund managers to exercise their skills. Some recent changes in the fund environment of New Zealand allows an examination of the impact on performance from those changes in a small, open economy.

Using a sample of New Zealand mutual funds, we compared performance before and after the introduction of two significant changes in the financial environment of New Zealand. In 2007, a state-sponsored investment scheme called KiwiSaver was introduced, providing significant incentives for more and more New Zealanders to save. Participation was substantial, and by 2015 KiwiSaver funds under management had exceeded traditional open-end funds. At the time of KiwiSaver's introduction, mutual fund regulation was quite lax, particularly in the area of financial disclosure. However, in 2013 a new law was introduced, substantially increasing the disclosure requirements for those funds 
participating in the KiwiSaver scheme. First we examined, the impact on the New Zealand mutual fund industry upon the introduction of KiwiSaver, and then on the introduction of the increased KiwiSaver regulation, in order to determine if these harmed the overall New Zealand mutual fund industry.

We found that the New Zealand mutual funds which focused on New Zealand or Australian equities experienced some negative performance after the introduction of KiwiSaver, but the impact on the overall industry was not significant. We also found that the increased regulation had some positive impact on performance, particularly for those funds emphasising global equities.

\section{Introduction}

Understanding the impact on mutual funds as a result of the introduction of new financial innovation and regulation is a matter of vital importance because all parties - investors, fund managers and regulators - want to know if performance has been positively or negatively impacted and whether outcomes will likely have implications for future policies. This study investigates the impact of regulatory changes in New Zealand, comparing results before and after the introduction of two important events in the financial environment. New Zealand's mutual fund industry has undergone significant changes in the last decade with the introduction of new financial regulation and initiatives. On July 2, 2007 KiwiSaver, New Zealand's voluntary work-based retirement (pension) savings scheme was introduced, focused mainly on employee and employer periodic contributions $^{1}$. Subsequently, on July 1, 2013 the new KiwiSaver Periodic Disclosure Regulation came into effect.

The New Zealand mutual fund industry is very small compared to the US, however since the introduction of the KiwiSaver scheme, total funds under management have grown substantially and investment participation has taken off. KiwiSaver was introduced in July 2007, and by June 2015 KiwiSaver had 2.53 million investors ${ }^{2}$, with NZD $\$ 32.8$ billion under management (see

Table 1). As of June 2015 the total population of New Zealand was 4.59 million $^{3}$ with 3.16 million in the workforce ${ }^{4}$, implying an $80 \%$ participation rate in KiwiSaver. Prior to KiwiSaver's introduction less than $30 \%$ of the active 
labour force was covered by a retirement plan (Kritzer, 2007). Furthermore, as noted in Table 1, as at the end of KiwiSaver's first full year (June 2008) there were $\$ 710$ million under management compared to $\$ 12.8$ billion in typical mutual funds. However, by June 2015, KiwiSaver had surpassed mutual funds, $\$ 32.8$ billion to $\$ 26.4$ billion.

Table 1. Relative growth in New Zealand's Open-End funds vs. KiwiSaver and other From Morningstar's "Fund Size-Comprehensive" In Millions \$ NZD, as of 30 June each year

\begin{tabular}{lccc}
\hline & Open-End & Kiwisaver & Other Super-annuation \\
\hline $\mathbf{2 0 0 8}$ & 12,809 & 710 & 2,905 \\
$\mathbf{2 0 0 9}$ & 13,769 & 2,547 & 3,745 \\
$\mathbf{2 0 1 0}$ & 15,169 & 5,046 & 4,079 \\
$\mathbf{2 0 1 1}$ & 16,283 & 7,885 & 5,300 \\
$\mathbf{2 0 1 2}$ & 19,115 & 11,082 & 4,989 \\
$\mathbf{2 0 1 3}$ & 19,452 & 17,181 & 5,249 \\
$\mathbf{2 0 1 4}$ & 23,779 & 23,719 & 5,471 \\
$\mathbf{2 0 1 5}$ & 26,429 & 32,832 & 6,326 \\
\hline
\end{tabular}

Since the introduction of KiwiSaver, both the global and local financial regulatory environments have changed significantly. After the global financial crisis in 2008, financial regulation came under considerable political review. The outcome in most developed economies was increased oversight and changes to regulatory structures and powers. New Zealand had the Financial Markets Authority Act 2011 (FMA Act) which saw the establishment of the Financial Markets Authority (FMA) in 20115, and in 2013 the Financial Markets Conduct Act 2013 (FMC Act) was introduced. While all changes are likely to have impacted the New Zealand mutual fund industry, this study's second focus is on KiwiSaver (Periodic Disclosure) Regulation 2013 (later revamped to the Financial Market Repeals and Amendments Act 2013) ${ }^{6}$ which came into force on July 1, 2013.

As the name suggests, the KiwiSaver Periodic Disclosure Regulation require fund managers to produce Quarterly Disclosure Statements and Annual Disclosure Statements, also known as QDS and ADS, respectively, for each KiwiSaver fund. QDS must be made publicly available by fund managers within 15 working days the end of each quarter and ADS within 60 working days. Disclosure statements help investors to evaluate fund performance and fees, to know what the major investments of the fund are, and to make comparisons with other funds. This is easier under the new regulation, due to an increased consistency of information.

There is an extensive financial literature on mutual fund performance dating back many decades. However, a dearth of academic studies exists on New Zealand mutual fund performance. With the relatively recent introduction 
and growing size and importance of KiwiSaver, a few empirical studies have appeared in recent years focussed on KiwiSaver performance. Our focus, however, is on the wider New Zealand mutual funds industry, and how the introduction of KiwiSaver has affected the rest of the New Zealand mutual fund landscape.

Our main research questions are: How did risk-adjusted fund performance change as a result of 1) the introduction of KiwiSaver and 2) the introduction of the KiwiSaver Periodic Disclosure Regulation?

We pose these questions to help build our understanding of the impact of financial market innovation and regulation on mutual fund performance. Ultimately, further studies could shed more light on many other important detailed questions ${ }^{7}$, but in this study our interest is to better understand how markets perform with respect to financial regulation.

To examine the effect of the introduction of KiwiSaver (KS) on New Zealand mutual fund performance, we examined the eight year period before and after the September 1, 2007 introduction of KS. The second event is the introduction of the KiwiSaver Periodic Disclosure Regulation (KSPDR), evaluated with two year periods pre- and post-KSPDR introduction on July 1, 2013. To measure risk-adjusted performance, we use the familiar CAPM, Fama and French (1993) three-factor model, and Carhart (1997) four-factor model.

Following Frijns and Tourani-Rad (2015) this study evaluates fund performance by measuring exposure to New Zealand and Australasian equity markets. We extend this method by grouping equity funds by regional investment focus to select an appropriate benchmark on four groups: New Zealand, Australia, Australasia (funds investing in New Zealand and Australia), and Global.

We find that the overall impact of introducing the KiwiSaver funds has been positive for the industry, with more investment participation by New Zealanders, and little performance impact. We also find that the impact of the increased regulation has had no negative impact, and may have helped in investment participation. It is our view that this implies that extending similar regulation to the rest of the industry is probably good for the industry as well.

\section{Literature Review}

\subsection{Mutual Fund Excess Performance Evaluation}

A substantial collection of academic studies have examined mutual fund performance. They provide a well-considered pathway of literature, methodology and results to review. At the heart of mutual fund performance evaluation, with respect to methodology, are the Capital Asset Pricing Model (CAPM) and Jensen's Alpha.

The development of the CAPM is largely attributed to Sharpe (1964), Lintner (1965), Mossin (1966), Treynor (1961a) and Treynor (1961b) all 
independently developing similar theories. CAPM derives the expected or required rates of return on risky assets based on the assets' systematic risk relative to a market portfolio.

Jensen (1968) created a portfolio performance measure we now call Jensen's Alpha which measures a fund manager's investment ability to underperform or outperform the market. This is done by rearranging the CAPM and utilising an intercept that we call alpha $(\alpha)$. A statistically significant and positive alpha indicates superior performance or outperformance, while a negative alpha highlights inferior performance or underperformance.

Multifactor models have since extended the CAPM and Jensen's Alpha model. The two most influential are the three-factor model of Fama and French (1993) and the four-factor model of Carhart (1997).

The Fama and French (1993) three-factor model seeks to specify microeconomic risk with the addition of two factors, SMB and HML. SMB (small minus big) is a proxy designed to capture firm size risk elements by building and measuring the return on a portfolio of small-cap stocks minus the return on a portfolio of large-cap stocks. HML (high minus low) is a proxy based on risk differentials regarding growth versus value stocks. The return on a portfolio of high book-to-market (value) stocks minus the return on a portfolio of low bookto-market (growth) stocks yields the proxy HML.

Carhart (1997) took the Fama and French (1993) three-factor model and combined it with the work of Jegadeesh and Titman (1993) by adding a fourth factor, momentum (WML). WML (winners minus losers) is a price momentum factor which takes the past year price performance of the highest performing equal-weighted group minus the lowest performing equal-weighted group.

\subsection{United States Research Results}

Prior academic studies have uncovered a variety of results. In the under performance camp Jensen (1968), Carhart (1997), Fama and French (2010), Otten and Thevissen (2011), Ferreira, Keswani, Miguel, and Ramos (2012), plus many others - all found that mutual funds underperform the market on a risk-adjusted basis. However, in the outperformance camp there were also notable studies such as by Kosowski, Timmermann, Wermers, and White (2006) and Petajisto (2013).

Performance persistence is one particular subset of mutual fund performance that is extensively researched, also with mixed results. Grinblatt and Titman (1992), Elton, Gruber, and Blake (1996), Goetzmann and Ibbotson (1994), S. Brown and Goetzmann (1995), Elton, Gruber, Das, and Hlavka (1993) and Wermers (1997) all found some evidence of positive performance persistence. Conversely, Jensen (1969) and Carhart (1997) found no evidence of performance persistence. 
In recent years specific issues have been examined that look to explain performance by other factors such as risk and style choices, fund size, fund family size, fund flows. Chen, Hong, Huang, and Kubik (2004), Pollet and Wilson (2008) Gil-Bazo and Ruiz-Verdú (2009) found that mutual fund performance is positively related to the size of the family to which the fund belongs.

\subsection{New Zealand Research Results}

Research on New Zealand mutual fund performance is relatively scarce. Vos, Brown, and Christie (1995) conducted a test of performance persistence on 14 New Zealand and 12 Australian equity mutual funds available to New Zealand investors during the period, 1988 to 1994 . In this small sample they found that past fund performance ranking for both raw returns and risk-adjusted returns had no predictive value for the next period ranking.

Bauer, Otten, and Rad (2006) conducted a performance test of 143 funds from 1990 to 2003 controlling for survivorship-bias and found no evidence of outperformance by New Zealand mutual funds. However, they did find evidence of significant underperformance for balanced funds. In further tests they discovered a positive relationship between fund size and risk-adjusted performance, as well as for fund size and expense ratio.

The recent research trend has been to focus specifically on KiwiSaver funds. Fund and member flows were examined by Thomas and Matthews (2014), who found a positive association between performance and both fund flow and member flow. They also found some rather inconclusive results relating to fund size with respect to fund flow. Zhang (2014) examined the impact that financial advice had on asset allocation decisions of investors and determined that there was marginal difference between fund performances of those that were advised versus those that were not advised.

The individual KiwiSaver Growth fund performance for 19 funds was evaluated by Frijns and Tourani-Rad (2015). They found no evidence of underperformance when regressing excess fund returns on the excess returns of the NZX50 index and the ASX200 index. In fact they found outperformance by six of the 19 funds. They also compared the performance of each find using the CAPM, the Fama-French three-factor model and the Carhart four-factor model. In all but one case, the alphas were negative, suggesting underperformance once we control for the specific factors in each model. The Fama-French three-factor model is a better fit than the CAPM with improved $R^{2}$ results. In many cases, the three-factor model better explains returns than the regression based on the two local market indices. However, the addition of the momentum factor in the Carhart four-factor model does not increase the goodness of fit in most cases.

Trainor (2014) evaluated the performance of the top 10 KiwiSaver providers, making up $97.8 \%$ of assets. A total of 68 funds were assessed and categorised as either equity, balanced or conservative based on percentage 
exposure to equity. A value-weighted category average return was calculated using total assets, then compared against an engineered value-weighted asset allocation benchmark. As a whole, he found underperformance, with equity funds performing less than desirable. Trainor (2014) also performed regression analysis controlling for a number of other variables, again, he found no evidence of outperformance. However, interestingly he did find a significant positive correlation with the asset allocation benchmark, a lagged benchmark factor and the SMB factor.

\subsection{Regulation and Mutual Funds}

There is a substantial amount of research on regulatory changes concerning disclosures. Bhojraj, Cho, and Yehuda (2012) studied the effect of significant regulatory changes on the previously noted positive relationship between mutual fund family size and fund performance. Specifically, they considered regulatory changes as being designed to reduce selective access to firm information, late trading and market timing opportunities. They found a significant weakening of that positive relationship after the regulatory changes. Tang (2013) assessed the impact of business connections from when a fund manager had previously worked as a sell-side analyst, and found that outperformance on those selected stocks decreased after Regulation Fair Disclosure (aka Reg FD) in 2000.

Ge and Zheng (2006) and Parida and Teo (2016) evaluated the impact that more frequent portfolio disclosures had on mutual fund performance, after the May 2004 Securities and Exchange Commision (SEC) regulation increased portfolio holdings disclosures frequency from semi-annual to quarterly. They found that mutual fund performance was adversely affected by the increase in disclosure frequency.

Also examining that SEC change was a comprehensive and detailed analysis conducted by Agarwal, Mullally, Tang, and Yang (2015) on stock liquidity and performance impact. They found that, in general, the new disclosure requirements deteriorated the performance of funds, but liquidity improved. Others, such as Verbeek and Wang (2013), Frank, Poterba, Shackelford, and Shoven (2004), Chen, Gallagher, and Lee (2017), Brown and Schwarz (2011), Schwarz and Potter (2016), Shi (2017), and Aragon, Hertzel, and Shi (2013) examined potential detrimental impact on funds' return from mimicking or front-running. The evidence was mixed, but there seemed to be some negative return impact from more frequent disclosure.

There are many US-based studies relating to disclosure, but few specifically on Australia or New Zealand. Using privately collected data, (Chen et al., 2017) examined copycat (mimicking) behaviour in Australia, finding potential for differential performance, depending on whether a top or a bottom performing fund was being considered. 
New Zealand did not have disclosure regulation for mutual funds until 2013, and Australia still does not. Brown and Gregory-Allen (2012), later updated as Gregory-Allen, Ozer Balli, and Thompson (2018), evaluated the potential effects of mandated holdings disclosure for Australian and New Zealand mutual funds. This was done by utilising data from funds that were voluntarily disclosed and comparing them to those that did not. They found that voluntary disclosures did not harm fund returns and concluded that mandatory disclosures benefited investors on the whole. The current study differed from others in that we examine the impact of a new pension fund scheme, and then the new regulation, of the overall mutual fund industry in New Zealand.

\section{Data}

We drew monthly returns (net of fees) data from the Morningstar database for all ${ }^{8}$ New Zealand open ended, active, equity mutual funds during the period of September 1999 to August 2015, including 30 funds which terminated during that period. Using Morningstar's “Global Category”, funds were classified according to each fund's investment focus:

a) New Zealand - primarily New Zealand stocks

b) Australian - primarily Australian stocks

c) Australasian ${ }^{9}$ - both New Zealand and Australian stocks

d) Global - multinational

In each case, this was the region that the fund reported as their focus of investment.

We examined all equity funds (including "dead" funds), only excluding those with fewer than 12 monthly returns. In our final sample there were 109 funds, of which 21 were New Zealand, eight were Australian, 32 were Australasian (funds investing in both Australia and New Zealand), and 48 Global. We did not include KiwiSaver funds, as we wanted to examine the impact of KiwiSaver scheme's introduction on the rest of the industry.

Tables $1-3$ show how the fund industry has grown over this period, both in dollar terms (Table 1) and in the number of funds. For example, for funds investing in New Zealand only, there were as few as four prior to KiwiSaver, but as many as 16 in the period after the scheme's introduction. Regarding total investment, in KiwiSaver's first full year there was a total of \$16.4 billion NZD of invested funds (including funds invested in KiwiSaver), and this quadrupled to $\$ 65.6$ billion NZD in 2015 . 
Table 2. Descriptive statistics before and after introduction of KiwiSaver (KS)

\begin{tabular}{|c|c|c|c|c|c|c|c|}
\hline \multirow{2}{*}{\multicolumn{2}{|c|}{ Total Num of funds }} & \multicolumn{3}{|c|}{ Number in any given month } & \multicolumn{3}{|c|}{ Monthly returns } \\
\hline & & Min & Max & Avg & Obs & Mean & SD \\
\hline \multicolumn{8}{|c|}{ Panel A: 16 year period ( 8 years pre $\& 8$ years post-KS) } \\
\hline New Zealand equity & 21 & 4 & 16 & 11.4 & 192 & 0.36 & 3.44 \\
\hline Australian equity & 8 & 2 & 8 & 5 & 192 & 0.26 & 4.55 \\
\hline Australasian equity & 32 & 5 & 26 & 14.7 & 192 & 0.54 & 3.30 \\
\hline Global equity & 48 & 13 & 37 & 24.8 & 192 & -0.22 & 3.96 \\
\hline \multicolumn{8}{|c|}{ Panel B: 8 year period (pre-KS) } \\
\hline New Zealand equity & & 4 & 12 & 8.5 & 96 & 0.59 & 3.46 \\
\hline Australian equity & & 2 & 6 & 3.4 & 96 & 0.49 & 4.07 \\
\hline Australasian equity & & 5 & 13 & 7.5 & 96 & 0.69 & 3.44 \\
\hline Global equity & & 13 & 21 & 17.6 & 96 & -0.42 & 4.55 \\
\hline \multicolumn{8}{|c|}{ Panel C: 8 year period (post-KS) } \\
\hline New Zealand equity & & 12 & 16 & 14.3 & 96 & 0.14 & 3.42 \\
\hline Australian equity & & 6 & 8 & 6.6 & 96 & 0.03 & 5.00 \\
\hline Australasian equity & & 13 & 26 & 21.8 & 96 & 0.39 & 3.16 \\
\hline Global equity & & 21 & 37 & 31.9 & 96 & -0.03 & 3.29 \\
\hline
\end{tabular}

Table 3. Descriptive statistics before and after introduction of KiwiSaver Periodic Disclosure Regulation (KSPDR)

\begin{tabular}{|c|c|c|c|c|c|c|c|}
\hline \multirow{2}{*}{ Total Num of funds } & & \multicolumn{3}{|c|}{ Number in any given month } & \multicolumn{3}{|c|}{ Monthly returns } \\
\hline & & Min & Max & Avg & Obs & Mean & SD \\
\hline \multicolumn{8}{|c|}{ Panel A: 4 year period ( 2 years pre \& 2 years post-KSPDR) } \\
\hline New Zealand equity & 21 & 13 & 16 & 14.6 & 48 & 0.92 & 2.01 \\
\hline Australian equity & 8 & 6 & 8 & 7.0 & 48 & 0.38 & 2.94 \\
\hline Australasian equity & 32 & 22 & 26 & 24.0 & 48 & 0.90 & 1.97 \\
\hline Global equity & 48 & 30 & 37 & 32.9 & 48 & 0.69 & 2.25 \\
\hline \multicolumn{8}{|c|}{ Panel B: 2 year period (pre-KSPDR) } \\
\hline New Zealand equity & & 13 & 15 & 14 & 24 & 0.88 & 2.29 \\
\hline Australian equity & & 7 & 7 & 7 & 24 & 0.30 & 3.35 \\
\hline Australasian equity & & 23 & 25 & 24.1 & 24 & 0.80 & 2.28 \\
\hline Global equity & & 31 & 34 & 32.1 & 24 & 0.38 & 2.79 \\
\hline \multicolumn{8}{|c|}{ Panel C: 2 year period (post-KSPDR) } \\
\hline New Zealand equity & & 14 & 16 & 15.1 & 24 & 0.95 & 1.73 \\
\hline Australian equity & & 6 & 8 & 7.1 & 24 & 0.47 & 0.47 \\
\hline Australasian equity & & 22 & 26 & 23.8 & 24 & 1.01 & 1.65 \\
\hline Global equity & & 30 & 37 & 33.6 & 24 & 1.00 & 1.55 \\
\hline
\end{tabular}




\section{Method}

To examine the impact of the introduction of KiwiSaver (KS), and the introduction of the KiwiSaver Periodic Disclosure Regulation (KSPDR), we estimated regressions for the overall New Zealand fund industry before and after each of these events. As we had sufficient data available, for KS, we estimated regressions eight years before and after 1 Sep 2007 (hence Sep 1, 1999 to Aug 31, 2007, and Sep 1, 2007 to Aug 31, 2015). With less available data, for KSPDR we used two years before and after 1 July 2013 (hence July 1, 2011 to June 30, 2013 and July 1, 2013 to June 30, 2015). For both the eight and two year periods, there were an equal number of observations before and after our two "events" of 1 Sep 2007 and 1 July 2013.

In each case, for each category described above - a) New Zealand equity, b) Australian equity, c) Australasian equity, d) Global equity - we formed an equally weighted portfolio of all funds in that category. We then estimated regressions based on models from CAPM, Fama- French (1993) and Carhart (1997):

$$
\begin{aligned}
& R_{i, t}=\alpha_{i}^{J}+\beta_{i} R M R F_{t}+\varepsilon_{i, t} \\
& R_{i, t}=\alpha_{i}^{F F}+b_{i} R M R F_{t}+s_{i} S M B_{t}+h_{i} H M L_{t}+\varepsilon_{i, t} \\
& R_{i, t}=\alpha_{i}^{C}+b_{i} R M R F_{t}+s_{i} S M B_{t}+h_{i} H M L_{t}+w_{i} W M L_{t}+\varepsilon_{i, t}
\end{aligned}
$$

where $R_{i, t}$ is the excess return (of the NZ 90-day bank bill rate) on the relevant portfolio of funds, RMRF is the excess return on a global market portfolio, SMB, HML and WML are factor proxies for size, book-to-market and momentum (winners-losers) from Fama-French (1993) and Carhart (1997), respectively. Then, $\chi_{i}^{J}, \alpha_{i}^{F F}$, and $\alpha_{i}^{C}$ are the CAPM (aka Jensen) alpha, Fama-French alpha and Carhart alpha, respectively. We used these alphas to measure risk-adjusted outperformance.

In order to gauge the impact of KS and the KSPDR, we also examined the change in this outperformance from before and after our two "events". Specifically, we used the difference-in-means test, which takes into account possible differences in the distributions, before and after. So, for example, the test for difference in the CAPM (Jensen) alpha across the introduction of KiwiSaver is:

$$
\begin{aligned}
& S E_{\alpha_{J_{2}-} \alpha_{J_{1}}}=\sqrt{\left(\frac{\sigma_{\alpha_{J_{1}}}^{2}}{n_{1}}\right)+\left(\frac{\sigma_{\alpha_{J_{2}}}^{2}}{n_{2}}\right)} \\
& T_{\alpha_{J_{2}-\alpha_{J_{1}}}}=\frac{\bar{\alpha}_{J_{2}} \bar{\alpha}_{J_{1}}}{S E_{\alpha_{J_{2}}-\alpha_{J_{1}}}}
\end{aligned}
$$




\section{Empirical Results}

In Table 1 we show how total dollars invested has increased from the time KiwiSaver was introduced until 2015. In 2008, the first full year of KiwiSaver availability, \$NZD 16.4 billion was invested in the combination of open-end funds, KiwiSaver funds, and other superannuation funds, of which only $\$ 710$ million was in KiwiSaver. KiwiSaver investment grew rapidly nearly matching open-end funds in 2014 at just under \$24 billion, and then in 2015 surpassing open-end with \$32.8 billion to open-end's \$26.4 billion. We also note that with the introduction of KiwiSaver regulation, the amount invested in KiwiSaver almost doubled from 2013 to 2015.

Tables 2 and 3 provide descriptive statistics about the fund portfolios, KS, and KSPDR. In general, raw returns were lower in the post-KS period, which is not surprising given that this period was almost entirely during the global financial crisis. In the post-KSPDR period, raw returns were higher, which may be mostly due to increased participation. However, it is important to note that in some periods some portfolios had a very small number of funds. This is especially true for the Australia portfolio where, in the early years of the pre-KS period (Table 2), there were as few as two funds. This suggests that these results should be taken with a substantial grain of salt.

As noted above, raw returns are shown in both Tables 2 and 3, and risk adjusted returns are reported in Tables 4 and 5. In the period around the introduction of KiwiSaver (Table 4), there are not many significant alphas, especially once we consider 3 and 4 factors. Of the Carhart alphas, only Australasian funds over the entire period are barely significant (at the 10\% level). For KSPDR, many more of the alphas are significant, and most improved in the post-KSPDR period. For example, the entire group ("All Equity") went from an insignificant 0.27 to a significant 0.62 . However, our real interest is in the significance of the changes in these alphas. For that we used the difference-in-means test, the results of which are reported in Tables 6 and 7.

From the eight year period, prior to KS to the eight year period after (see Table 6) most of the alphas decreased substantially. However, a note of caution is warranted; as with most analysis of New Zealand stocks, our sample size is quite small. For example, as noted earlier there were on average only five funds primarily covering Australia, with as few as two in the early years of our sample. There were more funds primarily covering New Zealand - on average about 11 but as few as four in the early years. The Global funds do show improvement over these periods, but only for the CAPM and Fama-French risk models. Considering all the funds, there are about 56 funds on average and none of the changes in alpha are significant at the $1 \%$ level. This suggests that although KiwiSaver has had a substantial impact on the number of New Zealanders investing and there may have been isolated instances of some traditional funds experiencing detrimental performance. For the overall industry what impact there was can probably be attributed to the GFC. 


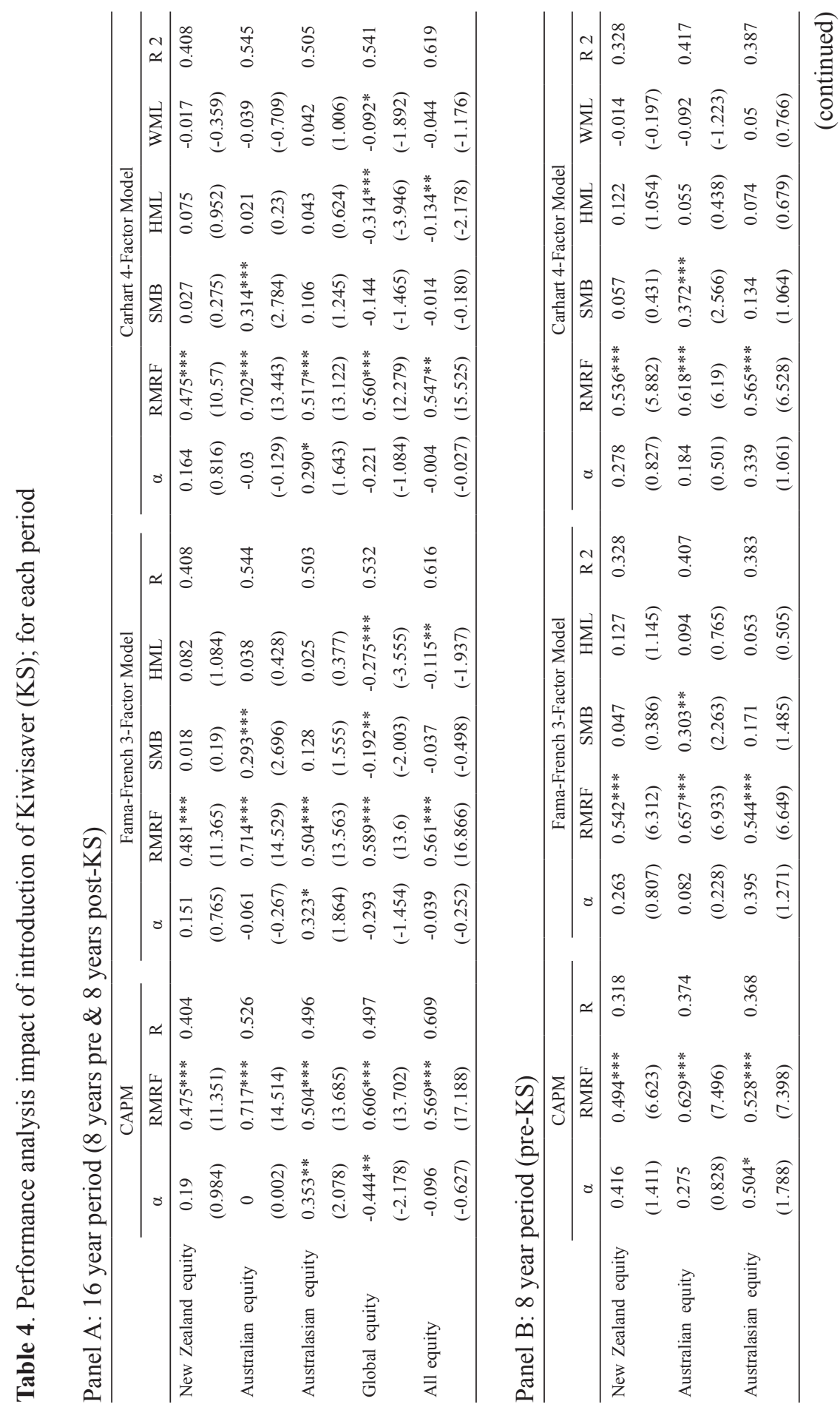




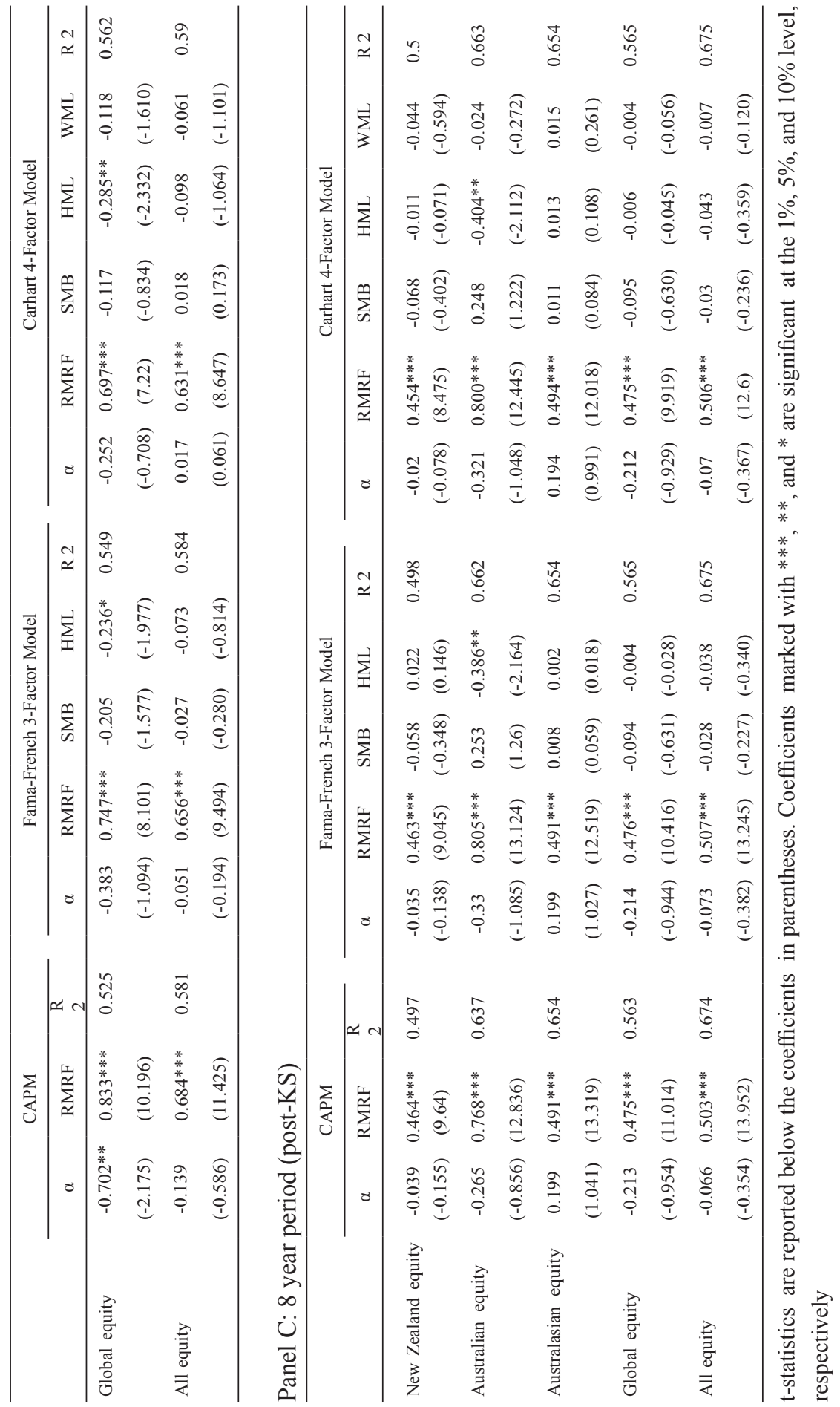




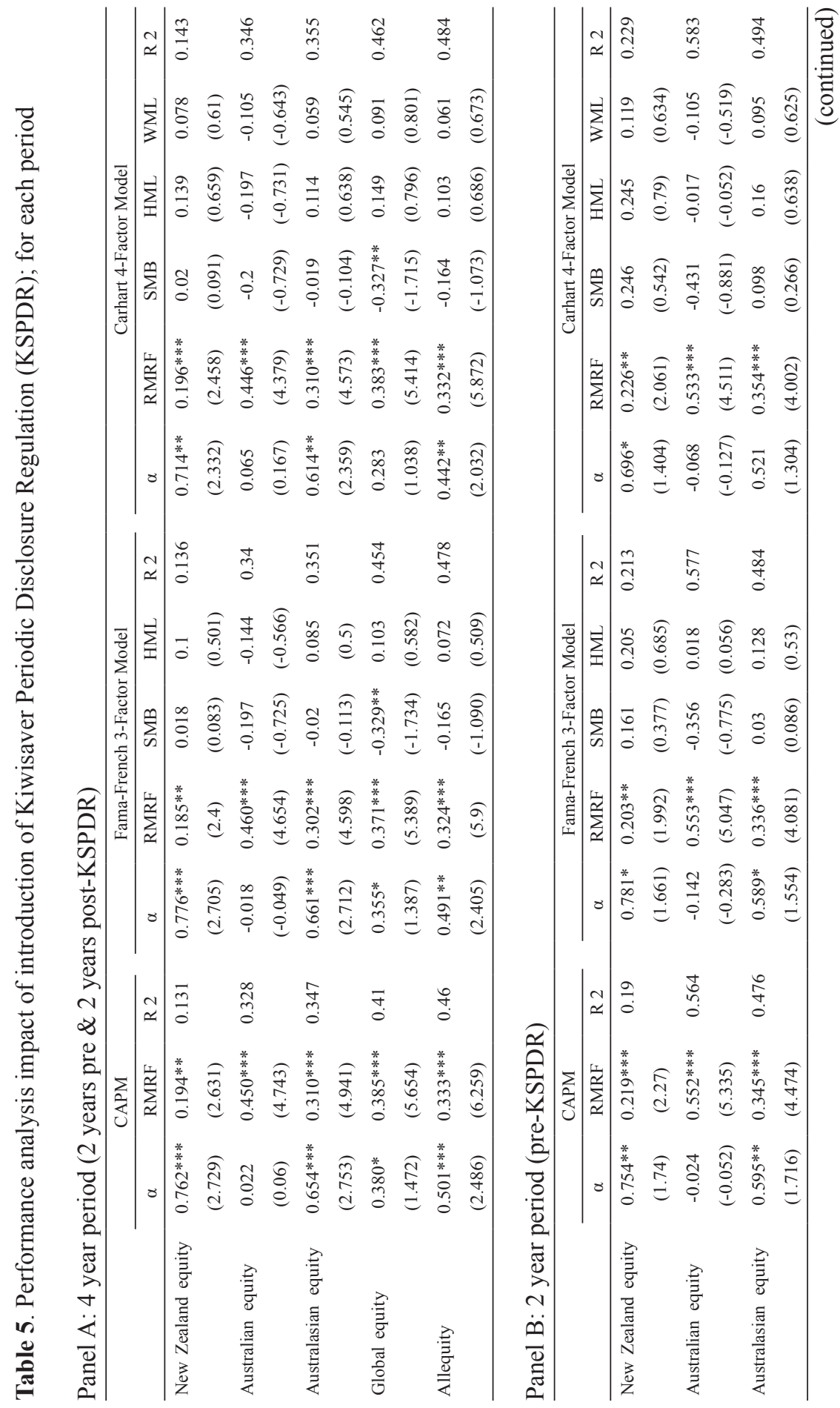




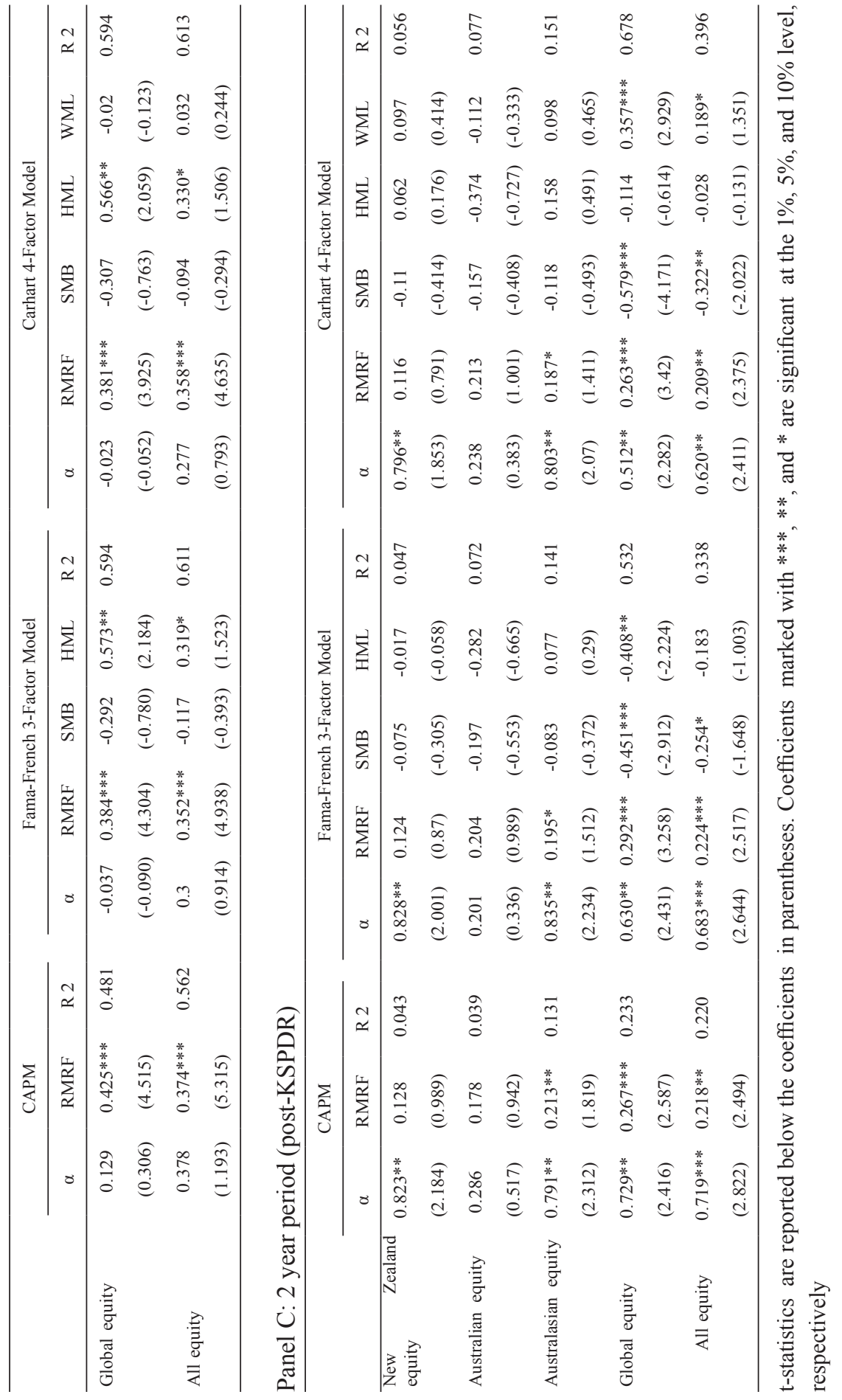


For the two years before and after the KSPDR, there is again the problem of small samples for some of the categories. However, most of the categories, notably the Global funds, do have an improvement in performance.

Table 6. Impact of introduction of Kiwisaver (KS)

- 8 years before and after 1 Sept, 2007

\begin{tabular}{lccll}
\hline & $\begin{array}{c}\text { Avg Num of } \\
\text { Funds }\end{array}$ & $\begin{array}{c}\text { CAPM } \\
\text { alpha }\end{array}$ & $\begin{array}{c}\text { FamaFrench } \\
\text { alpha }\end{array}$ & $\begin{array}{c}\text { Carhart } \\
\text { alpha }\end{array}$ \\
\hline New Zealand equity & 11.4 & $-0.45(-.29)$ & $-0.3^{* * *}(-3.23)$ & $-0.3 * * *(-3.16)$ \\
Australian equity & 5.1 & $\begin{array}{c}-0.54^{* * *} \\
(-5.32)\end{array}$ & $-0.41^{* * *}(-3.91)$ & $-0.51 * * *(-4.72)$ \\
Australasian equity & 14.7 & $\begin{array}{c}-0.31^{* * *} \\
(-4.01)\end{array}$ & $-0.2 * *(-2.39)$ & $-0.14 *(-1.73)$ \\
Global equity & 24.8 & $0.49^{* * *}$ & $0.17^{*}$ & 0.04 \\
& & $(5.57)$ & $(1.82)$ & $(.42)$ \\
All & \multirow{2}{*}{55.9} & 0.07 & -0.02 & -0.09 \\
& & $(1.07)$ & $(-.3)$ & $(-1.17)$ \\
\hline
\end{tabular}

Table 7. Impact of Introduction of Kiwisaver Periodic Disclosure Regulation (KSPDR)

- 2 years before and after 1 July, 2013

\begin{tabular}{lclll}
\hline & $\begin{array}{c}\text { Avg Num of } \\
\text { Funds }\end{array}$ & $\begin{array}{c}\text { CAPM } \\
\text { alpha }\end{array}$ & $\begin{array}{c}\text { FamaFrench } \\
\text { alpha }\end{array}$ & $\begin{array}{c}\text { Carhart } \\
\text { alpha }\end{array}$ \\
\hline New Zealand equity & 14.5 & 0.07 & 0.05 & 0.1 \\
& & $(.54)$ & $(.34)$ & $(.68)$ \\
Australian equity & 7.1 & $0.31^{*}(1.92)$ & $0.34^{* *}(1.96)$ & $0.31^{*}(1.67)$ \\
Australasian equity & 23.9 & $0.2^{*}(1.8)$ & $0.25^{* *}(2.07)$ & $0.28^{* *}(2.26)$ \\
Global equity & 32.9 & $0.6^{* * *}(5.17)$ & $0.67^{* * *}(6.14)$ & $0.53^{* * *}(4.86)$ \\
All & & & & 0.38 \\
\end{tabular}

T-statistics reported below coefficients, in parentheses. Coefficients marked with ***,**, and $*$ are significant at the $1 \%, 5 \%$, and $10 \%$ level, respectively 


\section{Conclusion}

This study examines the impact on the mutual fund industry of introducing a major superannuation scheme into a small economy, and the impact of increased regulation on the scheme. KiwiSaver, New Zealand's new superannuation scheme, has dramatically increased the investment participation rate of the labour force, resulting in funds invested in the scheme overtaking standard mutual funds by 2015, with a four-fold increase in total overall fund investment. With regard to mutual fund performance, a comparison of the risk-adjusted returns in the eight year period after KiwiSaver to the prior eight years shows a significant deterioration in some categories of the funds. However, especially due to small sample sizes, our overall evidence for a significant impact is weak. Given the dramatic improvement in investment participation by New Zealanders, we can readily conclude that overall, the introduction of KiwiSaver funds has been positive.

We draw a similar conclusion for the new law, the KiwiSaver Periodic Disclosure Regulation. In comparing mutual fund performance in the two year period after the regulation change to the prior two years, we found some significant improvement and no evidence for a negative impact. This shows that the increased regulation have not harmed fund performance and may well have contributed to the rapid inflow of invested dollars into KiwiSaver funds.

Obviously, these results for New Zealand are not conclusive for other small economies, but they are suggestive. While it is clear that KiwiSaver has substantially improved participation in retirement savings throughout the workforce, and that KiwiSaver Periodic Disclosure Regulation improved the KiwiSaver's overall safety, this study has shown that both have not had a broad, deleterious effect on the existing mutual fund environment.

\section{End Notes}

1 There is an initial $\$ 1000$ contribution from the government, then a (currently) minimum combined contribution rate of $6 \%$.

2 KiwiSaver Statistics available from http://www. KiwiSaver. govt. nz/statistics/

3 Population Statistics as of June 30, 2015 available from Statistics New Zealand http://www.stats.govt.nz/browse_for_stats/population/estimates_and projections/NationalPopulationEstimates_HOTPAt30Jun15.aspx

4 Data from Bloomberg

5 More information about the FMA and its role https://fma.govt.nz/fmas-role/ what-we-do/our-role/

6 For legislative information http://www.legislation.govt.nz/regulation/public/ 2013/0047/latest/whole.html 
7 For example, what is impact of regulatory change on fund managers performance?, does increased regulation lead to elimination of small funds or industry consolidation, or increased fund administrative costs?, what is effect of fund size, flows, or characteristics?

8 To avoid survivor bias we include all funds.

9 Although we use the term "Australasian" it includes only Australia and New Zealand; we use this term (rather than, say 'combined') to avoid confusion with a combination of the first two sets.

\section{References}

Agarwal, V., Mullally, K. A., Tang, Y., \& Yang, B. (2015). Mandatory portfolio disclosure, stock liquidity, and mutual fund performance. The Journal of Finance, 70(6), 2733-2776.

Aragon, G. O., Hertzel, M., \& Shi, Z. (2013). Why do hedge funds avoid disclosure? Evidence from confidential 13F filings. Journal of Financial and Quantitative Analysis, 48(5), 1499-1518.

Bauer, R., Otten, R., \& Rad, A. T. (2006). New Zealand mutual funds: Measuring performance and persistence in performance. Accounting \& Finance, 46(3), 347-363.

Bhojraj, S., Cho, J. Y., \& Yehuda, N. (2012). Mutual fund family size and mutual fund performance: The role of regulatory changes. Journal of Accounting Research, 50(3), 647-684.

Brown, K., \& Gregory-Allen, R. (2012). The potential effects of mandatory portfolio holdings disclosure in Australia and New Zealand. Available at SSRN 2131992. doi:https://papers.ssrn.com/sol3/papers.cfm?abstract id $=2131992$

Brown, S., \& Goetzmann, W. N. (1995). Performance persistence. The Journal of Finance, 50(2), 679-698.

Brown, S., \& Schwarz, C. (2011). The impact of mandatory hedge fund portfolio disclosure. Available at SSRN 1683628.

Carhart, M. M. (1997). On persistence in mutual fund performance. The Journal of Finance, 52(1), 57-82.

Chen, J., Hong, H., Huang, M., \& Kubik, J. D. (2004). Does fund size erode mutual fund performance? The role of liquidity and organization. American Economic Review, 94(5), 1276-1302.

Chen, Z., Gallagher, D. R., \& Lee, A. D. (2017). Testing the effect of portfolio holdings disclosure in an environment absent of mandatory disclosure. Accounting \& Finance, 57(S1), 101-116.

Elton, E. J., Gruber, M. J., \& Blake, C. R. (1996). The persistence of risk-adjusted mutual fund performance. Journal of business, 133-157. 
Elton, E. J., Gruber, M. J., Das, S., \& Hlavka, M. (1993). Efficiency with costly information: A reinterpretation of evidence from managed portfolios. The Review of Financial Studies, 6(1), 1-22.

Fama, E. F., \& French, K. R. (1993). Common risk factors in the returns on stocks and bonds. Journal of Financial Economics, 33(1), 3-56.

Fama, E. F., \& French, K. R. (2010). Luck versus skill in the cross section of mutual fund returns. The Journal of Finance, 65(5), 1915-1947.

Ferreira, M. A., Keswani, A., Miguel, A. F., \& Ramos, S. B. (2012). The flowperformance relationship around the world. Journal of Banking \& Finance, 36(6), 1759-1780.

Frank, M. M., Poterba, J. M., Shackelford, D. A., \& Shoven, J. B. (2004). Copycat funds: Information disclosure regulation and the returns to active management in the mutual fund industry. The Journal of Law and Economics, 47(2), 515-541.

Frijns, B., \& Tourani-Rad, A. (2015). On the performance of KiwiSaver funds. Pacific Accounting Review, 27(3), 266-281.

Ge, W., \& Zheng, L. (2006). The frequency of mutual fund portfolio disclosure.

Gil-Bazo, J., \& Ruiz-Verdú, P. (2009). The relation between price and performance in the mutual fund industry. The Journal of Finance, 64(5), 2153-2183.

Goetzmann, W. N., \& Ibbotson, R. G. (1994). Do winners repeat? Journal of Portfolio Management, 20(2), 9-18.

Gregory-Allen, R., Ozer Balli, H., \& Thompson, K. (2018). The impact of portfolio holdings disclosure on fund returns working paper.

Grinblatt, M., \& Titman, S. (1992). The persistence of mutual fund performance. The Journal of Finance, 47(5), 1977-1984.

Jegadeesh, N., \& Titman, S. (1993). Returns to buying winners and selling losers: Implications for stock market efficiency. The Journal of Finance, 48(1), 65-91.

Jensen, M. C. (1968). The performance of mutual funds in the period 1945-1964. The Journal of Finance, 23(2), 389-416.

Jensen, M. C. (1969). Risk, the pricing of capital assets, and the evaluation of investment portfolios. The Journal of Business, 42(2), 167-247.

Kosowski, R., Timmermann, A., Wermers, R., \& White, H. (2006). Can mutual fund "stars" really pick stocks? New evidence from a bootstrap analysis. The Journal of Finance, 61(6), 2551-2595.

Kritzer, B. E. (2007). KiwiSaver: New Zealand's new subsidized retirement savings plans. Soc. Sec. Bull., 67, 113.

Lintner, J. (1965). The Valuation of Risk Assets and the Selection of Risky Investments in Stock Portfolios and Capital Budgets. Review of Economics and Statistics, 47, 13-37.

Mossin, J. (1966). Equilibrium in a capital asset market. Econometrica: Journal of the econometric society, 768-783. 
Otten, R., \& Thevissen, K. (2011). Does industry size matter? Revisiting European mutual fund performance. Available at SSRN 1741197.

Parida, S., \& Teo, T. (2016). The impact of more frequent portfolio disclosure on mutual fund performance. Journal of Banking \& Finance.

Petajisto, A. (2013). Active share and mutual fund performance. Financial Analysts Journal, 69(4), 73-93.

Pollet, J. M., \& Wilson, M. (2008). How does size affect mutual fund behavior? The Journal of Finance, 63(6), 2941-2969.

Schwarz, C. G., \& Potter, M. E. (2016). Revisiting mutual fund portfolio disclosure. The Review of Financial Studies, 29(12), 3519-3544.

Sharpe, W. F. (1964). Capital asset prices: A theory of market equilibrium under conditions of risk. The Journal of Finance, 19(3), 425-442.

Shi, Z. (2017). The impact of portfolio disclosure on hedge fund performance. Journal of Financial Economics, 126(1), 36-53. doi:10.1016/j. jfineco.2017.06.001

Tang, Y. (2013). Business connections and informed trading of mutual fund managers. Available at SSRN 1741197.

Thomas, C., \& Matthews, C. (2014). KiwiSaver member behaviour: Aquantitative analysis. Pacific Accounting Review, 26(3), 248-273.

Trainor, W. J. (2014). Assessing KiwiSaver fund providers. New Zealand Journal of Applied Business Research, 12(2), 1.

Treynor, J. L. (1961a). Market value, time and risk. Unpublished manuscript.

Treynor, J. L. (1961b). Toward a theory of market value of risky assets. Unpublished manuscript, 6, 831-868.

Verbeek, M., \& Wang, Y. (2013). Better than the original? The relative success of copycat funds. Journal of Banking \& Finance, 37(9), 3454-3471.

Vos, E., Brown, P., \& Christie, S. (1995). A test of persistence in the performance of New Zealand and Australian equity mutual funds. Accounting Research Journal, 8(2), 19-35.

Wermers, R. (1997). Momentum investment strategies of mutual funds, performance persistence, and survivorship bias. Documento de Trabalho, University of Colorado.

Zhang, A. C. (2014). Financial advice and asset allocation of individual investors. Pacific Accounting Review, 26(3), 226-247. 